\title{
0013. Neuro-imaging and history of cases of refractory chronic cluster headache in young patients: a hint for reflections
}

\author{
Maria Nicolodi', Anna Torrini, Vanessa Sandoval, Manfredo Fanfani, Ivano Taddei \\ From Abstracts from the 1st Joint ANIRCEF-SISC Congress \\ Rome, Italy. 29-31 October 2015
}

\section{Background}

Hypothalamus has been suggested to be the crucial area of the brain for the stemming off of cluster headache $(\mathrm{CH})$ attacks [1-3].

\section{Aim}

To verify activation of brain areas during attacks in chronic, refractory young $\mathrm{CH}$ sufferers.

\section{Materials and methods}

The observation included 6 patients ( 6 males; aged 1821 years). The observation started in February 2011. Inclusion criteria were: diagnosis of chronic $\mathrm{CH}$ according to the ICHD-II, and patient refractory to any prophylactic and acute abortive treatment. In all the patients vegetative signs, characteristic of $\mathrm{CH}$ attack, were not observed, whilst VAS and behaviour measures showed excruciating pain. Exclusion criteria were: psychiatric illness (DMS IV parameters), epilepsy, CNS pathology evidenced with MRI. All the volunteers overused both sumatriptan and fentanyl, when they presented to our structure. Fentanyl and sumatripan gave very moderate benefits (mean 1.5, 05\% \pm 05.5 SD on $0-10$ VAS). The abuse lasted over 1 year (mean 3.6 years $\pm 1.2 \mathrm{SD}$ ). Nevertheless, it was impossible to obtain a real dis-habituation in these young sufferers. All patients, as well as one or both their parents, reported headache onset when the patient was 6 to 10 years old. Diagnosis of migraine without aura was made in accordance with the IHS criteria. It lasted for a period of 3-10 months (mean 4.1 $\pm 4.7 \mathrm{SD}$ ). Furthermore, migraine switched to $\mathrm{CH}$ and became chronic in a very short period (mean $3.3 \pm 1.4$ month SD). During the migraine period the 6 young

\footnotetext{
* Correspondence: sicuteri@iol.it

Foundation Prevention and Therapy Primary Pain and Headache, Florence, Italy
}

1. Nicolodi M, Sicuteri F, Poggioni M: Hypothalamic modulation of nociception and reproduction in cluster headache. Cephalalgia 1993, 13(4):253-257.

2. May A, Goasdby PJ: Hypothalamic involvement and activation in cluster headache. Curr Pain Headache Rep 2001, 5(1):60-66.

3. Leone M, Franzini A, Broggi G, Bussone G: Hypothalamic deep brain stimulation for intractable chronic cluster headache: a 3-year follow-up. Neurol Sci 2003, 24(Suppl 2):s143-s145. patients underwent a SPECT observation during attack. In tom was a moderate ipsilateral hypoperfusion at the fron-

\section{Results} outcomes, supports the suggestion that a thalamic gen-

\section{Conclusions}

It seems that the use of imigran sumatriptan and fentanyl tomic area of activation during the stemming off of $\mathrm{CH}$ attacks. This may suggest verifying the focus area in Written informed consent to publication was obtained from the patient(s).

\section{Published: 28 September 2015}


doi:10.1186/1129-2377-16-S1-A95

Cite this article as: Nicolodi et al: O013. Neuro-imaging and history of cases of refractory chronic cluster headache in young patients: a hint for reflections. The Journal of Headache and Pain 2015 16(Suppl 1):A95.

\section{Submit your manuscript to a SpringerOpen ${ }^{\mathcal{O}}$ journal and benefit from:}

- Convenient online submission

- Rigorous peer review

- Immediate publication on acceptance

- Open access: articles freely available online

- High visibility within the field

- Retaining the copyright to your article

Submit your next manuscript at $\gg$ springeropen.com 